\title{
Pendidikan Pancasila dan Pendidikan Agama Islam Dalam Konteks Kehidupan Beragama
}

\author{
Firman Mansir $^{1}$, Lia Kian ${ }^{2}$ \\ ${ }^{1}$ Universitas Muhammadiyah Yogyakarta \\ ${ }^{2}$ Perbanas Institute Jakarta \\ 1irmanmansir@umy.ac.id, $\underline{2}$ lia.kian@perbanas.id
}

\begin{tabular}{l}
\hline Keywords: \\
\hline Islamic \\
Education, \\
Pancasila, \\
Religious Life \\
\hline
\end{tabular}

Abstract
This study explains the position of Pancasila Education and
Islamic Religious Education in the context of religious life. There
are several forms of the dynamics of religious life such as
conflicts that usually occur in students, especially in various
Indonesian educational institutions. Conflicts that often occur in
schools are disputes between students, power struggles, small
problems that are often brought up and teenage love problems.
This phase students have begun to recognize feelings of love
between the opposite sex. The results show that the position
of Pancasila education and Islamic Religious Education is very
strategic and occupies. The forefront because they are the
mainstream in counteracting negative things for religious life.
So, they play an active role in overcoming various violence and
conflicts that occur in educational institutions. Thus, Pancasila
education and Islamic Education make efforts to guide future
generations of future candidates so that they can have a good
personality and are certainly. In accordance with the norms of
set by Islam itself through a strong religious understanding so
that there are no conflicts between them.

Kata Kunci:

Pendidikan

Agama Islam,

Pancasila,

Kehidupan

Beragama

\begin{tabular}{l} 
Abstrak \\
Penelitian ini menjelaskan mengenai posisi Pendidikan \\
Pancasila dan Pendidikan Agama Islam dalam konteks \\
kehidupan beragama. Terdapat beberapa bentuk dari dinamika \\
kehidupan beragama seperti konflik yang biasa terjadi pada \\
siswa terutama terjadi diberbagai lembaga pendidikan \\
Indonesia. Konflik yang sering terjadi di sekolah yaitu \\
perselisihan antar siswa, pertentangan adu kekuatan, masalah \\
kecil yang sering kali dibesarkan dan masalah percintaan remaja \\
yang dimana pada fase ini para siswa sudah mulai mengenal \\
perasaan suka antar lawan jenis. Hasil penelitian menunjukkan \\
bahwa posisi Pendidikan Pancasila dan Pendidikan Agama \\
Islam sangat strategis dan menempati garda terdepan karena \\
keduanya sebagai arus utama dalam menangkal hal-hal negatif \\
bagi kehidupan beragama, sehingga ia berperan aktif untuk \\
\hline
\end{tabular}


menanggulangi berbagai kekerasan dan konflik yang terjadi di lembaga pendidikan. Dengan demikian, Pendidikan Pancasila dan Pendidikan Agama Islam melalukan upaya untuk membimbing calon generasi penerus di masa depan agar dapat memiliki kepribadian baik dan pastinya sesuai dengan normanorma yang telah ditetapkan oleh agama Islam itu sendiri melalui pemahaman agama yang kuat agar tidak terjadi berbagai konflik diantara mereka.

\section{Pendahuluan}

Pendidikan berasal dari kata didik yang berarti memelihara atau juga melatih, (Abuddin Nata, 2010). Diartikan dari melatih dan memilihara berarti memerlukan sesuatu yang dapat dijadikan sebagai perantara dalam melakukan kegiatan ini, (Mansir, 2020). Seperti misalnya dalam ruang lingkup lembaga pendidikan, dalam mendidik seseorang (siswa) diharuskan memiliki tujuan yang pasti dan terarah dalam upaya pencapaiannya. Dalam pendidikan tentu saja dibutuhkan seseorang (guru) yang dapat mengarahkan siswa untuk menjadi lebih baik dari pada sebelumnya, (Walidaik, 2017). Hal ini dikarenakan ada beberapa guru yang dalam memberikan pendidikan kepada siswa kurang baik, sehingga menyebabkan siswa kurang mendapatkan pendidikan yang cukup. Sebagai bentuk upaya, diharapkan untuk guru di masa ini bisa memberikan pendidikan yang berkualitas kepada para siswa, (Mansir, 2019). Selain untuk melahirkan generasi yang lebih baik, dari adanya pendidikan seeorang akan lebih banyak memahami bagaimana ilmu itu akan diimplementasikan pada kehidupan luar ataupun kehidupan bermasyarakat.

Pendidikan Pancasila dan Pendidikan Agama Islam (Fathani \& Purnomo, 2020) memiliki arti upaya dalam mencapai tujuan keberhasilan siswa yang dimana dalam upaya tersebut seorang guru mempunyai keharusan untuk mempersiapkan para siswa untuk mengenal, memahami, mendalami hingga mengimani ajaran Islam serta menjalankan kewajiban yang memang sudah seharusnya dilakukan dalam ajaran Islam itu sendiri. Namun pengertian tersebut hanya sebatas pengertian singkat dari Pendidikan Agama Islam (Mansir, 2021). Kehadiran Pendidikan Agama Islam sebenarnya untuk menuntun dan membimbing para siswa supaya tetap berada pada jalan atau jalur yang benar, (Sanusi, 2013). Hal ini dikarenakan semakin lama zaman akan semakin berubah, semakin banyak pula tingkah laku atau perilaku yang kurang sesuai dengan aturan yang ada pada Pendidikan Agama Islam itu sendiri. Khususnya untuk kondisi sekarang ini, dunia sudah semakin tua dan teknologi yang berkembang sudah semakin pesat. Tentu saja ini menjadi 
kekhawatiran para sarjana muslim dan semua sebagai calon penerus generasi muslim yang tentunya akan menjadi tanggungjawab bersama ke depannya.

Dalam ajaran agama Islam, terdapat hukum tersendiri untuk menjalankan kegiatan atau mengatur norma-norma kehidupan yang sudah berlaku, (Mansir, 2020). Hukum Islam yang dapat dipahami dan dipelajari yaitu berasal dari al-Qur'an dan al-Hadis. Di dalam al-Qur'an telah tertulis lengkap mengenai cerita terdahulu, perintah dan larangan, bagaimana kebiasaan orang-orang terdahulu, atau juga kebiasaan nabi dan rasul yang sudah seharusnya dijadikan sebagai contoh suri tauladan dalam menjalankan kehidupan. Terdapat banyak pesan dan moral yang telah terkandung dalam al-Qur'an. Oleh karena itu sudah menjadi hal yang seharusnya kita lakukan untuk mengimani serta melaksanakan sesuai dengan yang telah tercantum pada pedoman umat Islam hingga akhir zaman nanti. Pada dasarnya tidak ada yang sulit dalam melaksanakan berbagai macam perintah dan menjauhi berbagai larangannya, yang membuat kita sebagai umat muslim sering meniggalkan perintah dan melaksanakan larangan yang telah tertulis. Hal ini dikarenakan sebagai umat Islam sering melalaikan pedoman agamanya sendiri. Terutama saat ini kita berada dan berhadapan dengan generasi millenial atau generasi kekinian yang dimana semua informasi bisa didapatkan dengan mudah dari smartphone saja.

Dalam mengaksesnya juga sangat mudah, hanya dibekali dengan kuota data ataupun smartphone yang sudah tersambung dengan wi-fi maka smartphone yang digunakan dapat disambungkan dengan akses internet tanpa batas. Berkenaan dengan hal itu, tidak sedikit informasi yang tersaji dalam internet merupakan hal yang layak dikonsumsi. Ada berbagai situs yang memberikan hal kurang senonoh untuk disajikan kepada khalayak umum. Terutama apabila anak dibawah umur juga tidak luput menikmati salura tersebut. Ini yang menjadi kekhawatiran umat Islam saat ini, orang tua memberikan anak fasilitas smartphone untuk dipergunakan dengan baik dan dapat dipergunakaan untuk belajar atau juga mengakses yang sekiranya bisa menambah ilmu pengetahuan si anak akan tetapi justru itu seakan menjadi boomerang orang tua itu sendiri. Hal tersebut dikarenakan sedikit seorang anak dan masing- masing dari kita menggunakan smartphone dan internet tersebut untuk mengorek sesuatu yang seharusnya perlu dijauhi.

Dari banyaknya pedoman Islam yang berlaku, seharusnya ini membuat masyarakat sebagai umat muslim semakin mudah dalam menjalankan kesehariannya. Namun kembali lagi, yang seringkali menjadi penghalang untuk taat dalam beribadah 
yaitu terdapat pada diri sendiri. Oleh karenanya, fungsi Pendidikan Agama Islam disini untuk membenahi kekeliruan dan melengkapi kekurangan yang masih menjadi persoalan umat Islam dalam menjalankan kehidupannya (Mansir, 2020). Ini menjadi kewajiban bagi pendidik saat ini terutama untuk calon pendidik yang di masa depan besok sudah harus siap untuk mendidik dan membimbing para murid atau peserta didik untuk menjadi generasi Islam yang berilmu (Mansir, 2019). Tentu dalam upaya tersebut terdapat banyak ujian dan tantangan supaya target yang diinginkan dapat tercapai. Sehingga diperlukan kesiapan ilmu dan juga pendirian agar berhasil mencapai tujuan pendidikan yag maksimal.

Seberapakah pentingnya Pendidikan Agama Islam dalam kehidupan? Seperti yang diketahui bahwasanya Pendidikan Agama Islam sangatlah memiliki pengaruh yang besar di dalam kehidupan seorang muslim. Hal ini dikarenakan pada dasarnya setiap manusia memerlukan pedoman untuk melanjutkan kehidupan dan mengarungi luasnya arus perjalanan hidup ini. Maka dari itu, Pendidikan Agama Islam memiliki posisi teratas dalam mengambil peran untuk menyiapkan kehidupan seorang muslim. Akan tetapi permasalahan yang sedang terjadi yakni Pendidikan Agama Islam mengalami "persaingan dengan pendidikan Barat. Terdapat banyak faktor yang mempengaruhi minat dalam mempelajari Pendidikan Agama Islam, bagi umat Islam Indonesia.

Faktor ini beberapa diantaranya berasal dari dalam sekolah namun juga dari luar sekolah. Salah satu faktor yang berasal dari dalam sekolah yaitu dimana ketika pada sekolah negeri jam pembelajaran pada mata pelajaran Pendidikan Agama Islam tidak memiliki porsi yang banyak. Sehingga hal ini membuat minat peserta didik dalam mempelajari pendidikan agama Islam tidak terlalu mendalam. Apalagi asupan yang diberikan sekolah negeri yakni ilmu-ilmu umum yang menyebabkan ilmu agama Islam pada sekolah negeri tidak lagi dibutuhkan banyak. Dalam pendidikan agama Islam terdapat banyak petunjuk guna menangani setiap permasalahan yang ada. Seperti yang diketahui, terdapat berbagai macam konflik yang sudah pasti kita mengenalnya dan konflik tersebut sudah biasa terjadi pada bangku sekolah atau di lembaga pendidikan. Apakah konflik tersebut selalu mengenai kekerasan ataukah hanya sebatas konflik salah paham yang terjadi pada masing-masing siswa yang terlibat. 


\section{Metode}

Penelitian ini menggunakan pendekatan kualitatif, (Creswell et al., 2007). Karena itu kemudian, penelitian ini fokus dengan melihat berbagai konflik yang terjadi di lembaga pendidikan. Adapun data yang digunakan ada dua. Yaitu: dara primer dan data sekunder. Data primer yaitu data yang diperoleh dari jurnal nasional yang memperbincangkan tentang konflik siswa. Data ini kemudian dikumpulkan dan dianalis dengan metode deskripti-analitik. Selanjutnya data sekunder yaitu data yang diperoleh dari buku referensi yang berkaitan dengan konflik siswa. Data sekunder ini untuk memperkuat hasil penelitian dan melengkapi data yang masih kurang. Dengan demikian, data-data yang sudah terkumpul kemudian diberikan kode untuk untuk melihat perbedaan dan persamaan dengan apa yang peneliti telusuri, tentu dalam hal ini adalah mengenai konflik siswa di lembaga pendidikan. Hasil dari pengkodean data-data itu selanjutnya dianalisis sesuai dengan metodologi yang kemudian melahirkan data yang akurat.

\section{Hasil dan Pembahasan}

Pendidikan Agama Islam merupakan salah satu ilmu pendidikan yang terdapat pada setiap sekolah umum di Indonesia, (Mansir, n.d.). Lain halnya yang terdapat pada sekolah Islam swasta (Fauziyah, 2021). Pendidikan Agama Islam terbagi secara spesifik dalam mata pelajaran seperti Fiqh, Aqidah Akhlaq, Qur'an Hadis, dan Sejarah Kebudayaan Islam. Ilmu-ilmu yang diberikan tetaplah sama yang membedakan yaitu jika pada sekolah negeri hanya diberikan nama PAI dengan penjelasan secara umum, (Mansir, 2021). Pada pembelajaran PAI di sekolah Islam maka PAI akan terpecah dengan penjelasan secara detail. Terutama pembelajaran PAI pada sekolah negeri hanya diberikan waktu singkat yang dimana rata-rata waktu yang diberikan hanyalah 2 jam per satu jam pelajarannya selama seminggu. Sehingga dari alokasi waktu yang tersedia tersebut tidak memungkinan jika siswa akan mendapatkan banyaknya pengetahuan agama Islam yang memadai dan mendalam. Mungkin ini adalah salah satu faktor penyebab munculnya konflik-konflik antara siswa dengan siswa lainnya dikarenakan masing-masing dari mereka kurang memahami arti pentingnya Pendidikan Agama Islam. Karena jika dikaitkan dengan pendidikan Islam, semua yang ada pada dunia ini akan saling berkesinambungan satu sama lain.

Kemudian pelaksanaan dari mata pelajaran Pendidikan Agama Islam ini sendiri merupakan program dalam mengimplementasikan pendidikan mental-spiritual dan juga 
moral kepada para peserta didik, (Sanusi, 2013). Bagaimanapun juga peran pendidik atau guru mata pelajaran Agama Islam ini juga harus tetap memantau dan juga mengupayakan untuk melakukan perbaikan konsep materi pelajarannya, (Mumtahanah, 2018). Akan lebih baik lagi jika dalam menyajikan materi agama Islam ini diberikan konsep. pembelajaran yang menyenangkan supaya peserta didik tertarik untuk mempelajari lebih lanjut mengenai Pendidikan Agama Islam. Hal ini juga yang dapat peserta didik menyerap lebih mudah mengenai materi tersebut. Tujuannya adalah supaya peserta didik memahami dan mengenal lebih jauh tentang ilmu-ilmu agama Islam.

Pendidikan Agama Islam merupakan pendidikan untuk mengenal, mengetahui, memahami dan mengikuti aturan dan ruang lingkup agama Islam, (Mansir, 2020). Pendidikan berasal dari kata "didik" yang berarti memelihara atau pun melatih. Bila diartikan dari segi etimologi atau bahasa, Pendidikan Agama Islam yaitu proses dalam memberikan pengajaran atau bentuk kontribusi seorang pedidik baik dalam akhlak maupun kecerdasan berpikir. Kemudian jika diambil dari segi terminologi atau istilah, Pendidikan Agama Islam merupakan upaya sadar guna mewujudkan suasana belajar dan proses pembelajaran supaya siswa dapat mengembangkan potensi yang ada pada dirinya untuk lebih memperdalam spiritual keagamaan, self esteem, kepribadian yang baik, kecerdasan dalam akhlak, dan juga keterampilan yang nantinya akan ia implementasikan padaa lingkungan keluarga, masyarakat, dan negara.

Pendidikan Islam (Tarbiyah) diartikan dari melatih dan memilihara berarti memerlukan sesuatu yang dapat dijadikan sebagai perantara dalam melakukan kegiatan ini (Mansir, 2017). Seperti halnya dalam ruang lingkup sekolah, dalam mendidik seseorang (peserta didik) diharuskan memiliki tujuan yang pasti dan terarah dalam upaya pencapaiannya. Dalam proses pengenalan ini terdapat banyak faktor-faktor yang masih menjadi kendala dalam melakukan proses belajar mengajar Pendidikan Agama Islam. Entah dari dalam faktor eksternal guru maupun dari media ajar yang berguna untuk membantu guru dalam memperlancar kegiatan belajar mengajar ini. Sudah bukan rahasia lagi jika minat dalam belajar Pendidikan Agama Islam di sekolah Indonesia tidak terlalu besar.

Hal ini disebabkan jam belajar yang diberikan juga hanya terbatas, yaitu hanya sekitar dua jam setiap mata pelajaran. Sedangkan banyaknya materi yang seharusnya diberikan tidak cukup jika hanya diberikan melalui waktu dua jam tersebut. Terutama kendala pada siswa juga seharusnya menjadi pertimbangan pendidik itu sendiri 
dikarenakan tidak semua siswa yang ada dapat langsung memahami isi dari materi ajar itu sendiri. Belum lagi jika terdapat beberapa anak yang tidak dapat menangkap materi pembelajaran tersebut, ini menyebabkan pendidik atau guru agama Islam tersebut mengalami kebingungan sendiri. Selain tujuan tercapainya materi ajar tidak tersampaikan secara maksimal kepada siswa, ia juga menjadikan hal ini sebagai evaluasi agar kedepannya mengenai materi atau pun segala bahan ajar yang telah ia berikan kepada peserta didik dapat diterima dengan baik. Pendidikan Agama Islami memiliki istilah atau makna tersendiri dari beberapa pengertian diantaranya:

1. Pendidikan Agama Islam merupakan pendidikan yang dikembangkan dari ajaran dan nilai-nilai yang terkandung dalam sumber dasar ajaran Islam.

2. Pendidikan Agama Islam merupakan upaya untuk mengajarkan kepada kaum muslimin untuk menjadikan ajaran Islam sebagai pedoman hidup seseorang.

3. Pendidikan agama Islam merupakan ajaran yang sudah ada sejak zaman Rasulullah hingga saat ini masih berkembang berkaitan dengan agama Islam dan sejarah umat Islam.

Dari beberapa istilah yang telah disebutkan di atas tersebut dapat ditarik benang merahnya jika Pendidikan Agama Islam merupakan upaya untuk membimbing calon generasi penerus di masa depan nanti agar dapat memiliki kepribadian baik dan pastinya sesuai dengan norma-norma yang telah ditetapkan oleh agama Islam itu sendiri (Sinaga, 2017). Dari sinilah nantinya akan lahir generasi penerus yang berkepribadian baik. Jika seseorang telah memiliki kepribadian muslim pastinya nanti ia menjadikan ajaran Islam sebagai pandangan atau pedoman hidupnya (Mansir, 2020). Tentunya juga dari cara berpikir dan menyikapi suatu tindakan sesuai dengan ajaran dan pandangan Islam. Dengan begitu tujuan dari Pendidikan Agama Islam merupakan sebuah upaya yang berupa bimbingan baik secara jasmani atau rohani kepada peserta didik secara Islami. Semua ini dilakukan untuk mencapai kebahagiaan yang sesungguhnya, yaitu kebahagiaan dunia dan akhirat.

Seperti yang telah disebutkan dalam penjelasan sebelumnya, posisi Pendidikan Pancasila, (Dewantara, 2015) dan Pendidikan Agama Islam sangatlah penting (Kuswanto, 2014), yakni berkaitan dengan ilmu-ilmu Islam yang menjadi fondasi dalam kehidupan perlu dikenal dan difahami betul. Hal ini juga dikarenakan Pendidikan Agama Islam bersifat urgent (penting) untuk dipelajari dari mulai zaman lahirnya Islam hingga akhir zaman nanti. Di dalam Al-Qur'an sudah diperjelas pada QS. Al-Baqarah ayat 159: 
Sungguh, orang-orang yang menyembunyikan apa yang telah Kami turunkan berupa keterangan-keterangan dan petunjuk, setelah Kami jelaskan kepada manusia dalam Kitab (Al-Qur'an)

\section{Ruang Lingkup Pendidikan Pancasila dan PAI di Indonesia}

Pada kajian Pendidikan Pancasila (Nurgiansah, 2021), sejatinya lingkup dan fungsi pancasila secara spesifik yaitu yang pertama, pancasila sebagai pedoman hidup bangsa (Rindjin, 2013). Indonesia bisa menjadikan pancasila sebagai pedoman dalam menyatukan hubungan dengan bangsa lain. Nilai-nilai pendidikan pancasila tidak boleh keluar atau melepaskan dari berbagai bentuk hubungan diplomatik yang terkoneksi dengan negara Indonesia terhadap negara lainnya (Suharyanto, 2013). Segala sesuatu yang terkait dengan hasil dalam konteks hubungan diplomatik perlu dipertimbangkan dengan menggunakan nilai pendidikan pancasila beserta makna yang terkandung dalamnya. Kedua, yaitu pancasila sebagai jiwa Negara Kesatuan Republik Indonesia (NKRI). Seluruh lembaga pendidikan maupun lembaga sosial di Indonesia baik yang besar maupun yang paling kecil seharusnya menjadikan pancasila sebagai nafas dan pedoman ideologinya. Ketiga, yaitu pancasila sebagaai kepribadian bangsa. Pancasila merupakan profile dan wajah bangsa. Sebagai profile, pancasila merupakan jawaban dari pertanyaan mengenai berbagai kepribadian Indonesia yang nyata.

Dengan demikian, pendidikan pancasila selanjutnya merupakan pancasila sebagai pedoman hukum (Fauzi et al., 2013). Maknanya adalah ia berfungsi sebagai sumber hukum dalam berbagai kasus di Indonesia. Hukum yang dibentuk, dimodel dan dibuat oleh seluruh pihak tidak seharusnya melupakan nilai-nilai pendidikan pancasila. Fungsi pendidikan pancasila juga sebagai cita-cita negara ini. Dasar negara Indonesia yang sudah dirancang sejak dulu oleh para pendiri bangsa memiliki pernyataan menarik yang menjadi harapan bangsa untuk diwujudkan oleh seluruh masyarakat bangsa Indonesia. Selanjutnya pendidikan pancasila berfungsi sebagai cita-cita bangsa maksudnya pancasila menjadi deskripsi serta penjelasan peta akan kemana bangsa Indonesia akan berjalan ke depannya. Dari berbagai fungsi pancasila diatas, dan tafsiran mengenai nilai pada pendidikan pancasila serta yang berkaitan dengan kehidupan berbangsa dan bernegara hendaknya tidak melenceng dari nilai-nilai pancasila itu sendiri (Amir, 2013). Sebab hal ini searah dengan nilai-nilai Pendidikan Agama Islam. Bisa dilihat secara gamblang tentang nilai-nilai yang terkandung dalam pancasila menurut (Widjajda: 2004) yaitu: 
a. Nilai Ketuhanan, nilai kemanusiaan, nilai persatuan, nilai kerakyatan dan nilai keadilan.

b. Nilai ideal, nilau material, nilai spiritual, nilai pragmatis, dan nilai positif.

c. Nilai etis, nilai estetis, nilai logis, nilai sosisal dan nilai religius.

Melihat dan mengamati penjelasan di atas, sepertinya nilai-nilai itu sudah terpancar dan terkandung dalam Pendidikan Agama Islam. Pancasila yang tidak luput dari nilai ketuhanan, spiritual, maupun religius dapat menjadi pedoman bagi bangsa Indonesia untuk tidak melupakan segi spiritual, hal tersebut juga tercantum dalam pembukaan UUD 1945. Hal tersebut dengan tegas menunjukkan bahwa Indonesia merupakan negara yang menggunakan landasan kepercayaan terhadap adanya Tuhan Yang Maha Esa. Hal serupa juga sesuai dengan perinsip yang terkandung dalam pedoman nilai-nilai karakter.

Sementara itu, ruang lingkup pendidikan Agama Islam mencakup keharmonisan, (Tolchah, 2020) keselarasan dan kesepadan antara hubungan manusia dengan Rabb-nya, hubungan manusia dengan manusia lainnya, dan kemudian hubungan manusia dengan dirinya sendiri. Tak luput juga hubungan manusia dengan makhluk Allah yang lainnya. Aspek-aspek yang terkandung pada Pendidikan Agama Islam juga menjadi penting. Ini akan menjadi perpaduan yang sama-sama saling melengkapi satu sama lain. Ruang lingkup Pendidikan Agama Islam yang biasanya dilaksanakan di sekolah umum maupun sekolah swasta Islam yakni ada Aqidah (Ilmu tentang keimanan), Ilmu Fiqh (Ilmu yang berkaitan dengan ibadah), Al Qur'an dan Hadits, Akidah Akhlak, dan juga Tarikh Islam, (Fauziyah, 2021).

Dari semua cabang ilmu pendidikan, baik itu Pendidikan Pancasila (Nishimura, 1995), dan khususnya Pendidikan Agama Islam yang ada di atas dapat ditarik benang merahnya bahwa secara mandiri atau tanpa harus mengikuti kegiatan belajar mengajar di sekolah. Ini dikarenakan cabang-cabang ilmu Islam tersebut merupakan ilmu umum yang artinya semua orang dapat mempelajarinya tanpa harus memiliki syarat tertentu untuk belajar ilmu tersebut. Terutama Islam mengharuskan umatnya untuk menuntut ilmu setinggi mungkin, terlebih untuk mempelajari agama hal ini memiliki poin lebih dan memang diwajibkan. Berbeda halnya dengan mempelajari ilmu-ilmu umum yang sifatnya tidak wajib meskipun ketika kita memasuki dunia sekolah pasti kita juga diwajibkan untuk mengikuti pelajaran tersebut. Akan tetapi, dilain waktu jika memiliki waktu lebih luang alangkah baiknya jika dimanfaatkan untuk menimba ilmu agama. 


\section{Implementasi Nilai-Nilai Pancasila dan Pendidikan Agama Islam}

Seperti yang telah diketahui bahwasanya tujuan dari pendidikan yakni sebagai proses atau upaya untuk menyiapkan masa depan anak didik untuk mencapai tujuan hidup yang tepat, (Walidaik, 2017). Berbagai upaya telah dilaksanakan hanya untuk menciptakan kehidupan yang lebih baik. Terutama saat ini sudah memasuki zaman dimana semuanya hanya mengandalkan internet sebagai rutinitas kesehariannya. Sehingga ini membuat seseorang untuk lebih mawas diri dalam menggunakan dan memanfaatkan internet agar tidak tersesat dalam menggunakannya. Maka peranan pendidikan agama Islam disini supaya anak didik mampu mengendalikan perilakunya agar tidak seenaknya dalam mengambil sikap. Ini dikarenakan anak dan juga remaja rentan mengikuti atau meniru bagaimana orang sekitar dalam berperilaku. Oleh karenanya dalam Islam diberikanlah pedoman untuk hidup lebih baik supaya dapat memanfaatkan hidup yang singat in dengan sebaik-baiknya.

Berkaitan dengan nilai yang dapat diimplementasikan oleh siswa, maka pembelajaran yang dapat diterima oleh siswa seperti akhlak yang baik, yang dapat diimplementasikan dengan bagaimana cara bersikap yang baik atau menanggapi perilaku seseorang dengan baik juga tanpa harus berlaku kasar atau menyakiti, (Mumtahanah, 2018). Ini merupakan salah satu bentuk mengimplementasikan materi pembelajaran pendidikan Pancasila dan Pendidikan Agama Islam. Kemudian untuk bentuk implementasi materi pembelajaran al-Qur'an dan hadist dapat dilakukan dengan mengamalkan perilaku yang baik sesuai dengan yang telah diperintahkan dalam firman Allah SWT yang telah tertuliskan dalam al-Qur'an, dan kemudian bentuk pengamalan dari hadis sendiri dapat dilakukan dengan melakukan perilaku-perilaku terpuji dan menjalankan sunnah nabi seperti yang telah tercantum dalam hadis-hadis nabi yang hingga saat ini masih dipakai sebagai bentuk petunjuk selain al-Qur'an.

Dalam menyampaikan kebenaran juga menggunakan adab dan tutur kata yang baik, ini untuk menghindari diri sendiri dari menyakiti orang lain. Pendidikan Pancasila sangat konsen pada persoalan ini, sebab hal ini dapat mencerminkan sikap dan kepribadian seseorang sebagai anak bangsa. Dalam konteks Pendidikan Agama Islam (Hidayat, 2015), apabila orang lain merasa sakit hati karena perkataan yang keluar dari lisan seseorang, maka itu akan membuat individu mendapatkan dosa karena telah membuat orang lain terluka. Maka dari itu, di dalam Pendidikan Agama Islam, adab merupakan sesuatu hal yang penting. Selain ini merupakan bentuk impelementasi dari 
pembelajaran Akhlak juga bagian dari nilai-nilai Pendidikan Pancasila. Sebuah pepatah yang mengatakan bahwa percuma jika berilmu namun tidak memiliki adab yang baik. Maka dari itu adab sangat penting untuk diajarkan sejak dini. Hal ini selaras dengan semangat yang dimiliki Pendidikan Pancasila dalam mengajarkan kepada siswa tentang sikap hidup toleransi bermasyarakat.

Selanjutnya cara mengimplementasikan nilai Pendidikan Pancasila dan Pendidikan Agama Islam dalam kehidupan sehari-hari. Dapat dilakukan dengan cara mengamalkan nilai-nilai Pancasila sebagai falsafah kehidupan beragama dan berbangsa. Melaksanakan ibadah sesuai dengan tuntunan syari'atnya masing-masing. Dalam ilmu fiqh umat muslim diharuskan benar-benar sejalur dengan apa yang sudah diperintahkan. Karena jika keluar dari jalur dan tidak sesuai tuntunan maka itu sama saja menentang ajaran Islam yang sudah ada sejak Islam lahir. Ini juga merupakan antisipasi untuk tidak melakukan hal yang terlarang dalam melaksanakan ibadah. Pendidikan Pancasila sebagai pandangan hidup bangsa (way of life) memiliki makna Pancasila bagian pedoman dan pegangan dalam kehidupan serta memberikan tuntunan perilaku masyarakat bagsa Indonesia dalam konteks kehidupan bermasyarakat. Karena itu kemudian, sebagai sumber nilai dan etika, seperti halnya Pendidikan Agama Islam, maka nilai-nilai yang terdapat dalam pancasila sebaiknya diimplementasikan dalam kehidupan sehari-hari dengan tujuan terciptanya kehidupan masyarakat harmonis, dinamis, aman, tertib dan religius.

Contoh dalam konteks di sekolah adalah konflik pada siswa sering terjadi mulai pada saat masih berada di Taman Kanak-kanak hingga masa peserta didik sudah memasuki ke jenjang sekolah menengah atas. Tidak hanya sedikit permasalahan, tetapi bisa melahirkan segunung masalah. Mulai dari permasalahan kecil antar sesama teman, kesalah pahaman dengan teman kelas, atau mungkin dengan angkatan yang lebih tua atau muda dari peserta didik tersebut. Bahkan peserta didik juga melakukan kesalahan dengan guru mereka masing-masing yang tidak sengaja atau hanya sebatas salah paham. Tidak dapat dipungkiri jika datangnya permasalahan ini juga awalnya juga sebatas candaan atau masalah kecil, namun akhirnya malah berlanjut hingga memperpanjang masalah.

Pada masa sekolah, siswa biasanya mulai usil atau mulai bertingkah yang kurang baik pada saat remaja, (Ibda, 2012). Hal ini secara psikologis dikarenakan pada saat remaja hormon seseorang dapat dikatakan sedang tingi-tingginya. Sehingga ketika mereka mengambil keputusan dalam suatu masalah, terkadang belum berpikir secara 
tepat, atau dalam mengambil keputusan mereka masih belum bisa bertanggungjawab dengan pilihannya. Hal ini yang menjadikan ketika di usia tersebut remaja masihlah dikatakan labil, meskipun terdapat beberapa remaja yang juga sudah bisa menempatkan tanggungjawabnya.

Dari uraian di atas, mengungkap bahwa pendidikan pancasila dan pendidikan agama islam pada dasarnya memiliki muara dan misi yang sama, sehingga keduanya diperlukan dalam merespon berbagai persoalan peserta didik di lembaga pendidikan Indonesia, (Mansir, 2018). Oleh karena itu, dalam Pendidikan Pancasila dan Pendidikan Agama Islam, keduanya menyelesaikan suatu masalah dapat dilakukan dengan cara yang baik, bijaksana, adil, dan tidak saling menyalahkan satu sama lain. Sebagai bangsa Indonesia dan umat Islam harus bisa menerima dan memahami jika terdapat perbedaan yang ada. Karena perbedaan tersebut di dalam Islam lazimnya disebut sebagai rahmat. Maka dengan adanya perbedaan itu, akan menimbulkan adanya sikap saling menghormati, menghargai pendapat atau perbedaan orang lain. Tentu dalam konteks ini yang diharapkan adalah jiwa pancasila dan motivasi keagamaan yang diperlukan.

\section{Kesimpulan}

Pendidikan Pancasila dan Pendidikan agama islam merupakan salah satu ilmu pendidikan yang terdapat pada setiap sekolah umum di indonesia. Pendidikan Pancasila bagian dari nilai-nilai kebangsaan yang perlu ditularkan kepada peserta didik. Sementara Pendidikan agama Islam bagian dari proses untuk mengenal, mengetahui, memahami dan mengikuti aturan dan ruang lingkup agama Islam. Dari sini titik awal nantinya akan lahir generasi penerus yang berkepribadian baik, berwawasan global, cinta tanah air dan memiliki jiwa pancasila. Jika seseorang telah memiliki kepribadian muslim pastinya nanti ia menjadikan ajaran Islam sebagai pandangan atau pedoman hidupnya. Tidak hanya itu, ia juga menjadikan pancasila sebagai falsafah kehidupan bagsa. Dengan ini akan menjadikan Pendidikan Pancasila dan Pendidikan Agama Islam juga sebagai pedoman hidup manusia dan warga bangsa Indonesia.

\section{Daftar Pustaka}

Abuddin Nata, A. N. (2010). Ilmu Pendidikan Islam. Kencana Prenada Media Group. Amir, S. (2013). Pancasila as integration philosophy of education and national character. International Journal of Scientific \& Technology Research, 2(1), 54-57. 
Creswell, J. W., Hanson, W. E., Clark Plano, V. L., \& Morales, A. (2007). Qualitative research designs: Selection and implementation. The Counseling Psychologist, $35(2), 236-264$.

Dewantara, A. W. (2015). Pancasila Sebagai Pondasi Pendidikan Agama Di Indonesia. CIVIS, 5(1).

Fathani, A. T., \& Purnomo, E. P. (2020). Implementasi Nilai Pancasila dalam Menekan Radikalisme Agama. Mimbar Keadilan, 13(2), 240-251.

Fauzi, F. Y., Arianto, I., \& Solihatin, E. (2013). Peran guru Pendidikan Pancasila dan Kewarganegaraan dalam upaya pembentukan karakter peserta didik. Jurnal PPKn UNJ Online, 1(2), 1-15.

Fauziyah, N. (2021). Pengelolaan Kelas Dalam Pembelajaran Aqidah Akhlak Di Era Pandemi Covid-19 Pada Siswa Kelas V Di MI Darul Ulum Desa Benem Kecamatan Duduksampeyan Kabupaten Gresik. Universitas Muhammadiyah Gresik.

Hidayat, N. (2015). Peran dan Tantangan Pendidikan Agama Islam di Era Global. Jurnal Pendidikan Agama Islam, 12(1), 61-74.

Ibda, F. (2012). Pendidikan moral anak melalui pengajaran bidang studi PPKn dan pendidikan agama. JURNAL ILMIAH DIDAKTIKA: Media Ilmiah Pendidikan Dan Pengajaran, 12(2).

Kuswanto, E. (2014). Peranan Guru PAI dalam Pendidikan Akhlak di Sekolah. MUDARRISA: Jurnal Kajian Pendidikan Islam, 6(2), 194-220.

Mansir, F. (n.d.). The Response Of Islamic Education To The Advancement Of Science In The Covid-19 Pandemic Era In The Islamic Boarding Schools. AULADUNA: Jurnal Pendidikan Dasar Islam, 8(1), 20-27.

Mansir, F. (2017). Model Pendidikan Karakter Di Perguruan Tinggi Islam (Studi Pada Umi Dan Uin Alauddin Makassar).

Mansir, F. (2018). Diskursus Pendidikan Karakter di Peguruan Tinggi Keagamaan Islam pada Era Milenial. Tadrib, 4(2), 280-300.

Mansir, F. (2019). Implications of Teacher Certification on Professionalism and Welfare of 21th Century PAI Teachers. Tadrib, 5(2), 138-152.

Mansir, F. (2020). Diskursus Sains dalam Kurikulum Pendidikan Agama Islam di Sekolah dan Madrasah Era Digital. Kamaya: Jurnal Ilmu Agama, 3(2), 144-157. 
Mansir, F. (2020). Identitas Guru PAI Abad 21 Yang Ideal pada Pembelajaran Fiqh di Sekolah dan Madrasah. Muslim Heritage, 5(2), 435.

Mansir, F. (2020). The Leadership of Personnel Management in Islamic Education: Emerging Insights from an Indonesian University. Edukasia Islamika, 1-16.

Mansir, F. (2020). The Urgency of Fiqh Siyasah In Islamic Education Learning At Madrasas And Schools. POTENSIA: Jurnal Kependidikan Islam, 6(2), 142-154.

Mansir, F. (2021). Aktualisasi Pendidikan Agama dan Sains dalam Character Building Peserta Didik di Sekolah dan Madrasah. J-PAI: Jurnal Pendidikan Agama Islam, $7(2)$.

Mansir, F. (2021). The Urgency of Fiqh Education and Family Role in The Middle of Covid-19 Pandemic For Students In School and Madrasah. Kamaya: Jurnal Ilmu Agama, 4(1), 1-10.

Mumtahanah, M. (2018). Peranan Guru Pendidikan Agama Islam Dalam Mengatasi Perilaku Menyimpang Siswa. TARBAWI: Jurnal Pendidikan Agama Islam, 3(01), $19-36$.

Nishimura, S. (1995). The development of Pancasila moral education in Indonesia. Japanese Journal of Southeast Asian Studies, 33(3), 303-316.

Nurgiansah, T. H. (2021). Pendidikan Pancasila sebagai upaya membentuk karakter jujur. Jurnal Pendidikan Kewarganegaraan Undiksha, 9(1), 33-41.

Rindjin, K. (2013). Pendidikan pancasila untuk perguruan tinggi. Gramedia Pustaka Utama.

Sanusi, H. P. (2013). Peran Guru PAI Dalam pengembangan Nuansa religius di sekolah. Jurnal Pendidikan Agama Islam-Ta'lim, 11(2), 143-153.

Sinaga, S. (2017). Problematika pendidikan agama islam di sekolah dan solusinya. WARAQAT: Jurnal Ilmu-Ilmu Keislaman, 2(1), 14.

Suharyanto, A. (2013). Peranan pendidikan kewarganegaraan dalam membina sikap toleransi antar siswa. JPPUMA Jurnal Ilmu Pemerintahan Dan Sosial Politik Universitas Medan Area, 1(2), 12.

Tolchah, M. (2020). Problematika Pendidikan Agama Islam dan solusianya. Kanzun Books.

Walidaik, A. (2017). Peran Guru PAI Dalam Mengatasi Masalah Kenakalan Remaja (Studi Kasus Pada MA Darussalam Kemiri Kecamatan Subah Kabupaten Batang. IAIN SALATIGA. 